\title{
High-Order Thinking Skill in Solving Two-Dimensional Arithmetic Series Based on Bloom's Taxonomy
}

\author{
Zainal Abidin', Mohammad Tohir ${ }^{2}$ \\ ${ }_{1}^{1}$ Pelita Hati School of Jember, Indonesia \\ 2Universitas Ibrahimy, Situbondo, Indonesia \\ zainalabidin.school@gmail.com
}

\begin{abstract}
:
The research aims to describe the level of higher-order thinking skills ability of students in solving generalization patterns in two-dimensional arithmetic series based on revised Bloom's taxonomy. The research method used is a qualitative descriptive approach. The subjects were students of the Master Program of Mathematics Education at Jember University. The data was collected by giving open problem-solving tasks and documentation studies to students to develop patterns of onedimensional arithmetic series. Then, students are given the task of solving the next problem to draw up a generalization pattern of two-dimensional arithmetic series. The data analysis technique used is qualitative descriptive data analysis. The results showed that the percentage of higherorder thinking skills aspects included analyze (C4) reached 88.89\%, evaluate (C5) reached 83.33\%, and create (C6) reached $66.67 \%$. The results of this achievement are influenced by several factors, including accuracy in compiling numbers and expanding existing data, mastery of arithmetic series permutation concepts and their application, the tendency of graduate students to rely on memorization and imitations of existing examples.
\end{abstract}

Keywords: High-Order Thinking Skills, arithmetic series, two-dimensional, revised Bloom's taxonomy.

\section{Conclusions and Recommendations}

Based on the results of research and discussion that has been described previously, it can be concluded that:

1) Students' high-level thinking skills in combinatoric courses are found in the "creative (C6)" cognitive domain. Because from the description of the characteristics of high-level thinking skills in each of the cognitive domains obtained that students can meet most of the indicators of high-level thinking.

2) Based on the results of the analysis, the factors that influence students' highlevel thinking skills in combinatoric courses include the carefulness in expanding existing data to find function formulas, being careful in the form of existing parameters, the tendency of students to rely on memorization, imitation, and motivation. Meanwhile, to develop higher-order thinking skills students can be pursued by increasing motivation in developing concepts that have been taught by lecturers, doing exercises that are continuous in solving 
problems related to the material, and reading carefully the problems given so the ability to identify and analyze problems will be better.

3) Based on the results of an analysis of the cognitive realm of high-level thinking students, then students will be better if it is always done at any given time because high-level thinking someone always develops with age and is influenced by routine exercises. Biological maturity and development, as well as higher education, provide facilities for students to be able to develop thinking and behavior skills. One of the courses that can develop students' higher-order thinking skills is combinatorics and graphs. This way can develop students' high-level thinking skills. When students 'higher-order thinking skills begin to develop, the students' higher-order thinking levels do not only always reach the cognitive domain of "analyzing (C4)", but can also rise to the higher cognitive domain, namely the cognitive domain of "evaluating (C5)" or "Creating (C6)".

4) Students should be able to apply a meaningful learning process in receiving the material or concepts provided. Students must always be active in every learning and not only be focused on concepts taught by lecturers but must develop these concepts through the study of literature and exercises in the form of other patterns so that they will hone their high-level thinking skills.

5) It is expected that educators or researchers will always carry out varied and continuous research to students, especially those relating to combinatoric material and graphs. so that students' higher-order thinking skills can be trained and developed. Besides, educators or researchers should be able to apply meaningful learning that can activate and optimize the potential of students by being encouraged by various learning approaches.

\section{Citation:}

Abidin, Zainal, \& Tohir, Mohammad. (2019). High-Order Thinking Skill in Solving Two-Dimensional Arithmetic Series Based on Bloom's Taxonomy. Alifmatika: Journal of Mathematics Education and Learning, 1(1), 44-60. 


\section{DAFTAR PUSTAKA}

Abidin, Z., \& Tohir, M. (2019). Keterampilan Berpikir Tingkat Tinggi dalam Memecahkan Deret Aritmatika Dua Dimensi Berdasarkan Taksonomi Bloom. Alifmatika: Jurnal Pendidikan Dan Pembelajaran Matematika, 1(1), 44-60.

Anderson, L.W. \& Krathwohl, D. R. (2010). Kerangka Landasan Untuk Pembelajaran, Pengajaran, dan Asesmen (Terjemahan Agung Prihantoro). New York: Addition Wesley Longman. (buku asli diterbitkan tahun 2001).

Basrowi, S. (2008). Memahami Penelitian Kualitatif. Jakarta: Rineka Cipta.

Gartmann, S., \& Freiberg, M. (1995). Metacognition and Mathematical Problem Solving: Helping Students to Ask the Right Questions. Metacognition and Mathematical Problem Solving: Helping Students to Ask the Right Questions, 6(1).

Julistiawati, R., \& Yonata, B. (2013). Keterampilan Berpikir Level C4, C5, \& C6 Revisi Taksonomi Bloom Siswa Kelas X-3 SMAN 1 Sumenep pada Penerapan Model Pembelajaran Inkuiri Pokok Bahasan Larutan Elektrolit dan Non Elektrolit. Jurnal Teknologi, 1(1), 69-73. https://doi.org/10.11113/jt.v56.60

Narbuko, C. (2010). Metodologi Penelitian. Jakarta: Bumi Aksara.

Novitasari, D. (2016). Pengaruh Penggunaan Multimedia Interaktif Terhadap Kemampuan Pemahaman Konsep Matematis Siswa. FIBONACCI: Jurnal Pendidikan Matematika Dan Matematika, 8-18.

P21. (2014). Learning for the 21st Century: A Report and MILE Guide for. Retrieved from http://www.21stcenturyskills.org

Pohl, M. (2000). Learning to Think, Thinking to Learn. Thinking Education.

Ramos, J. L. S.; Dolipas, B. B.; \& Villamor, B. B. (2013). Higher Order Thinking Skills and Academic Performance in Physics of College Students: A Regression Analysis. International Journal of Innovative Interdisciplinary Research Issue, 4, 48-60. Retrieved from http://education.qld.gov.au/corporate/newbasics/html/pedagogies/intellect/int 1a.html

Rasyidin, L. F., \& Maulana F. (2008). Cara Mudah Menaklukkan Olimpiade Matematika SMP. Jakarta: Wahyu Media.

Saefudin, A. A. (2011). Proses Berpikir Kreatif Siswa Sekolah Dasar (SD) Berkemampuan Matematika Tinggi dalam Pemecahan Masalah Matematika Terbuka. Universitas PGRI Yogyakarta. Yogyakarta.

Sobirin, M.; Koes, S.; \& Kusairi, S. (2016). Level Keterampilan Berpikir Siswa Pada Materi Optika. Pros. Semnas Pend. IPA Pascasarjana UM, 1, 373-380.

Tohir, M., Abidin, Z., Dafik, D., \& Hobri, H. (2018). Students Creative Thinking Skills in Solving Two Dimensional Arithmetic Series Through Research-Based Learning. Journal of Physics: Conference Series. https://doi.org/10.1088/17426596/1008/1/012072

Tohir, Mohammad. (2017). Pengembangan Bahan Ajar Olimpiade Matematika Berdasarkan Model Pemecahan Masalah untuk Meningkatkan Kemampuan Penalaran Matematis Siswa. In Tesis. Magister Pendidikan Matematika Universitas Jember. Jember: Program Pascasarjana Universitas Jember. 